\title{
Quality of Care and Medication Adherence among Patients with Type (2) Diabetes Mellitus
}

\author{
Nagwa Nashat Hegazy MD ${ }^{(1)}$ \\ ${ }^{1}$ Family Medicine Department, Faculty of Medicine, Menoufia University
}

\begin{abstract}
Background: Diabetes mellitus (DM) is a wide-reaching prevailing metabolic syndrome. Better medical adherence improves the diabetic glycemic control and postpones the diabetes-related complications. A good perceived quality of care could improve the adherence and correspondingly the wellbeing of the diabetic patients. Objectives: were to assess treatment adherence in patients with type II diabetes, as well as the link between medication adherence and quality of care regarding the process and intermediate outcomes.

Methods: Patients with type 2 DM were recruited from Munshaat Sultan primary health center outpatient clinic, Egypt using a convenient sampling technique (150 participants).They were recruited over three months. All eligible participants were interviewed and their records were revised for the past year. The interviewing questionnaire contained three parts to sees the socioeconomic status, patient medication adherence, and quality of care perceived. Results: nearly half of the diabetic participants were low adherent resembling 55.3\% of the studied group. Most of the low adherent patients were female, illiterate and those without medical insurance. The main quality of care hindrances they pointed at were long waiting time and short consultation period. A statistical positive correlation was found between the adherence score and quality of care score and process of care score simultaneously.

Conclusion: this study showed that nonadherence of the diabetic patients is a prevailing problem.
\end{abstract}

Keywords: Diabetes, adherence, general practice, family medicine, facility services

Introduction: Diabetes mellitus $(\mathrm{DM})$ is a wide-reaching prevailing metabolic syndrome. The World Health Organization (WHO) had anticipated that DM is going to become the seventh most significant primary cause of death worldwide by the year 2030. ${ }^{(1)}$ It is the $11^{\text {th }}$ most significant reason for premature mortality in Egypt. It is blamable for nearly two percent of all years of life lost (YLL). Correspondingly, it is the $6^{\text {th }}$ chief reason of disability burden in Egypt. Thus the improvement of patient medication adherence will assist to decline these figures.

Adherence conceptually includes numerous types of health-related behavior and isn't just around taking prescribed medication. It is defined as "the extent to which the patient follows medical instructions". ${ }^{(2)}$ It had been reported that good medical adherence leads to better diabetic glycemic control and postponing of diabetes-related complications. ${ }^{(3)}$

Quality of care (QoC) had been defined by the WHO as 'the degree to which the health care amenities are provided to healthy and ill populations improve the 
anticipated health outcomes. Thus health care needs to be safe, efficient, timely, effective, equitable, and people-centered ${ }^{\prime(4)}$. Most of the health care quality improvement efforts object the measures of health care in the terms of structures, processes, and/or outcomes ${ }^{(5)}$. Two main chief dimensions of QoC for individual patients have been defined; access and effectiveness. Effectiveness is constituted of two main fundamentals termed clinical care effectiveness and inter-personal care effectiveness. These components could be discussed in the terms of the structure of the health care system, processes of care, and outcomes resulting from care ${ }^{(6)}$. Quality of care and adherence to medication are interrelated in the literature on diabetes. Theoretically, it is supposed that better quality of care will improve the medication adherence. However, the studies didn't examine that link. To the best of our knowledge, there was sacristy of conducted research on adherence and QoC in Egyptian diabetic patients. Therefore it seemed important to investigate the relation between these two parameters. The objectives of the current study aimed to assess medication adherence among patients with type 2 diabetes mellitus, as well as the link between medication adherence and domains of quality of care.

\section{Methods:}

The protocol of the study was approved by the Ethical Committee of the Faculty of Medicine, Menoufia University. An informed written patient consent was attained from each participant after explaining the research objectives. The study was a descriptive cross-sectional study performed in Munshaat Sultan primary health care center (PHC) which is an accredited PHC by the Egyptian Ministry of health and population (MOHP). The inclusion criteria for participants were having noncomplicated type 2 diabetes for over 2 years (diagnosed based on the American Diabetes Association criteria) ${ }^{(7)}$ taking oral hypoglycemic drugs (OHDs) once per day.

The sample size was calculated using EPI calculation program based on the prevalence of diabetic patients in Egypt which was $15.56 \%{ }^{(8)}$ and the population of Munshaat sultan which was 25,239 at 2016.According to the equation, the sample size was 128 patients and it was raised to 150 patients to overcome drop out. All the registered type $2 \mathrm{DM}$ patients attending the PHC from 10:00 am to 2: $00 \mathrm{pm}$ daily for 5 days during the period of study were invited to participate in the study. Data collection took place from March to June 2017. 
All participants were interviewed and their medical records were revised. Data was collected via a questionnaire consisting of three scales. The first part had included questions on socio-demographic characteristics. Furthermore, the socioeconomic status (SES) was evaluated based on Fahmy et al., socioeconomic scoring system. ${ }^{(9)}$ The second part was to evaluate patient adherence as an intermediate outcome of effectiveness through an Arabic validated Morisky adherence scale. ${ }^{(10)}$ It is an eightitem questionnaire with scores ranged from zero to eight. Score less than six is considered non-adherent while score more than six was considered adherent. The third part was designed to measure the QoC based on Mosadeghrad framework. ${ }^{(11)}$

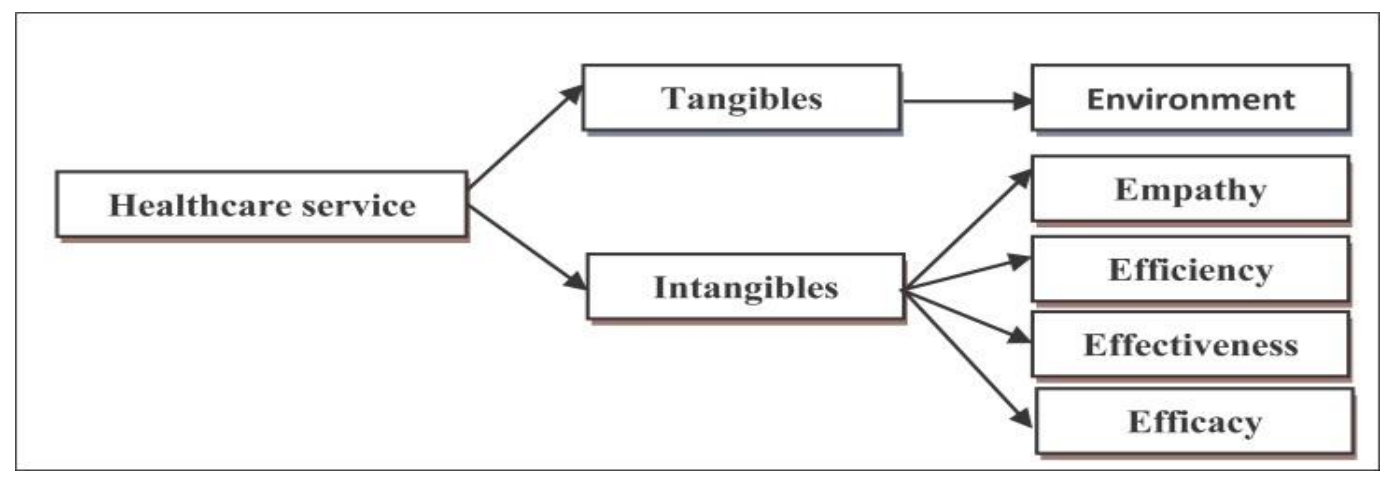

Figure (1): A conceptual framework for quality measurement in healthcare

It entailed two parts; the first part was to assess environmental and empathy domains through nine questions with 3 point -likert scale (agree, neutral, disagree). Then a score was calculated to assess the QoC received by the patient where a score of less than $60 \%$ was considered poor QoC. The second part was to assess the effectiveness and efficacy domain through using a checklist to evaluate the diabetic process of care. According to the recommendations of national guideline of MOHP, ${ }^{(12)}$ the process measures that could be considered as representative of quality of diabetes care ten basic items: blood pressure, blood glucose, proteinuria, peripheral pulses, peripheral sensations, foot examination, referral for doing an ophthalmic examination, assessment of urea, assessment of electrolytes, and assessment of glycosylated hemoglobin. Scoring system to assess the extent of fulfillment of ten items according to the national guideline in the past year was used where a point was considered on doing each item gains a point. The process of diabetic care was considered as, good by achieving 6-10 points and considered poor on achieving less than 6 points. 


\section{Statistical analysis:}

Data were collected, tabulated, statistically analyzed using an IBM personal computer with Statistical Package for Social Science (SPSS) version 20 where the following statistics were applied.

a- Descriptive statistics: in which quantitative data were presented in the form of a mean (), standard deviation (SD), range, and qualitative data were presented in the form numbers and percentages. b- Analytical statistics: used to find out the possible association between studied factors and the targeted disease. The used tests of significance included: 1-Student t-test: is a test of significance used for comparison between two groups having quantitative variables. 2- Pearson correlation (r): is a test used to measure the association between two quantitative variables. A probability value ( $P$-value) less than 0.05 was considered statistically significant and was high statistically signification if $P<0.01$ )

\section{Results:}

Most of the studied population were females (69.3\%), married (79.3\%), with basic primary education (65.3\%) and working (62\%). Half of the studied group were in the low socioeconomic status $51.3 \%$ (Table 1). Nearly half of the diabetic patients who had participated in the study were low adherent resembling $55.3 \%$ of the studied group (Figure 2). There was a statistically significant difference in the low adherence regarding sex, occupation, health insurance, and disease duration. Low adherence participants were mainly female $(\mathrm{P}<0.001)$, not working $(\mathrm{P}<0.001)$, without health insurance $(\mathrm{P}<0.001)$ and with lower disease duration $(\mathrm{P}=0.002)($ Table2).

Nearly $78 \%$ of the participants couldn't spend enough time with their doctors. Half of the participants had difficulties to conduct the necessary tests and to access to center (The center is far from the place of residence of one hundred patients).Almost $60.7 \%$ complained from the Long waiting time (Table 3). Nearly $70 \%$ of the participants had expressed obstacles during their visit to the healthcare facility (Figure 3). Nearly all the participants underwent weight and blood pressure measurement (Table 4). There was a statistically significant correlation between adherence score and $\mathrm{QoC}$ score $(\mathrm{P}=0.04)$ (figure 4). Also, there was a statistically significant correlation between adherence score and process of care score $(\mathrm{P}<0.001)$ (figure5). 


\section{Discussion:}

Nearly half of the participants had shown low adherence to oral hypoglycemic medications which is in agreement with Donnan et al., ${ }^{(13) .}$ Good adherence (Morisky score $\geq 6$ ) was linked with female sex and older age. Kirkman et al, had found that adherence was independently related to older age and male sex. ${ }^{(14)}$ The sex difference could be explained by the fact that the majority of the studied population in the current study were females. Presence of the environmental factors in the health care system was prevailing among the participants where 78\% didn't spend enough time with the physician and $66.7 \%$ had expressed that the center is far from their residence which is in agreement with Mosadeghrad and Ali. ${ }^{(15)}$

There was a statistically significant positive correlation between patientperceived experiences on environmental factors and the clinical outcomes in the form of adherence with is in agreement with Price et al., who found the positive relation between patients' use of services and health outcomes. ${ }^{(16)}$ There was a statistically significant correlation between adherence score and process of care score which is in agreement with Karapek et al, who found good HbA1C scores with high Morisky adherence scores ${ }^{(17) .}$ He stated that The Morisky score may be an effective tool for detecting patients with poor medication-taking behavior.

\section{Conclusion:}

Non-adherence of the diabetic patients is a vital problem. Primary health care services and quality of care provided is a keystone in shaping their adherence thus improving the healthcare service quality and the processes of care will improve patient adherence and reduce the frequency and severity of diabetic complication. Findings of the current study could be extrapolated to a large population.

\section{References}

1. World Health Organization. World Health Statistics 2017: Monitoring Health for the SDGs Sustainable Development Goals: WHO; 2017.

2. Sabaté E. Adherence to long-term therapies: evidence for action: World Health Organization; 2003.

3. Chew B-H, Hassan N-H, Sherina M-S. Determinants of medication adherence among adults with type 2 diabetes mellitus in three Malaysian public health clinics: a cross-sectional study. Patient preference and adherence. 2015;9:639.

4. World Health Organization. Quality of care: a process for making strategic choices in health systems. 2006. 
5. Donabedian A. The quality of care: how can it be assessed? Jama. 1988;260(12):1743-8.

6. Campbell SM, Roland MO, Buetow SA. Defining quality of care. Social science \& medicine. 2000;51(11):1611-25.

7. American Diabetes Association. Diagnosis and classification of diabetes mellitus. Diabetes care. 2014;37(Supplement 1):S81-S90.

8. Hegazi R, El-Gamal M, Abdel-Hady N, Hamdy O. Epidemiology of and Risk Factors for Type 2 Diabetes in Egypt. Annals of Global Health. 2015;81(6):814-20.

9. Fahmy SI, Nofal LM, Shehata SF, El Kady HM, Ibrahim HK. Updating indicators for scaling the socioeconomic level of families for health research. The Journal Of The Egyptian Public Health Association. 2015;90(1):1-7.

10. Ashur S, Shamsuddin K, Shah S, Bosseri S, Morisky D. Reliability and knowngroup validity of the Arabic version of the 8-item Morisky Medication Adherence Scale among type 2 diabetes mellitus patients. Eastern Mediterranean Health Journal. 2015;21(10):722.

11. Mosadeghrad AM. A Conceptual Framework for Quality of Care. Materia Socio-Medica. 2012;24(4):251-61.

12.Practice Guidelines for Family Physcians. Egypt. Volume 1[Last accessed on 2017 July]. From http://www.mohp.gov.eg/UserFiles/LibraryFiles/339699.pdf

13. Donnan PT, MacDonald TM, Morris AD. Adherence to prescribed oral hypoglycaemic medication in a population of patients with Type 2 diabetes: a retrospective cohort study. Diabetic Medicine. 2002;19(4):279-84.

14. Kirkman MS, Rowan-Martin MT, Levin R, Fonseca VA, Schmittdiel JA, Herman $\mathrm{WH}$, et al. Determinants of adherence to diabetes medications: findings from a large pharmacy claims database. Diabetes care. 2015;38(4):604-9.

15. Mosadeghrad AM. Factors influencing healthcare service quality. International journal of health policy and management. 2014;3(2):77.

16. Anhang Price R, Elliott MN, Zaslavsky AM, Hays RD, Lehrman WG, Rybowski L, et al. Examining the Role of Patient Experience Surveys in Measuring Health Care Quality. Medical Care Research and Review. 2014;71(5):522-54.

17. Krapek K, King K, Warren SS, George KG, Caputo DA, Mihelich K, et al. Medication Adherence and Associated Hemoglobin A1c in Type 2 Diabetes. Annals of Pharmacotherapy. 2004;38(9):1357-62. 
Table (1): Socio demographic data of studied group $(\mathrm{N}=150)$ :

\begin{tabular}{|c|c|c|}
\hline Socio demographic characteristics & No & $\%$ \\
\hline $\begin{array}{l}\text { Age/years: }\left(\bar{X}_{ \pm} \mathrm{SD}\right) \\
\text { Range }\end{array}$ & \multicolumn{2}{|c|}{$\begin{array}{l}44.9 \pm 4.1 \\
32-50\end{array}$} \\
\hline $\begin{array}{c}\text { Gender: } \\
\text { - Female } \\
\text { - } \quad \text { Male }\end{array}$ & $\begin{array}{l}104 \\
46\end{array}$ & $\begin{array}{l}69.3 \\
30.7\end{array}$ \\
\hline $\begin{array}{c}\text { Marital state: } \\
\text { - Single } \\
\text { - } \text { Married } \\
\text { - } \text { Widow } \\
\text { Divorce } \\
\end{array}$ & $\begin{array}{l}2 \\
119 \\
17 \\
12 \\
\end{array}$ & $\begin{array}{l}1.3 \\
79.3 \\
11.3 \\
8\end{array}$ \\
\hline $\begin{array}{l}\text { Educational level: } \\
\text { - } \text { Illiterate } \\
\text { - } \text { Basic } \\
\text { - Secondary } \\
\text { - } \text { University and above } \\
\end{array}$ & $\begin{array}{l}2 \\
98 \\
39 \\
11\end{array}$ & $\begin{array}{l}103 \\
65.3 \\
26 \\
7.3 \\
\end{array}$ \\
\hline $\begin{aligned} \text { Occupation: } \\
\text { - Not work } \\
\text { - Worker } \\
\text { - Technician } \\
\text { - Government employee }\end{aligned}$ & $\begin{array}{l}93 \\
7 \\
26 \\
24 \\
\end{array}$ & $\begin{array}{l}62 \\
4.7 \\
17.3 \\
16 \\
\end{array}$ \\
\hline $\begin{array}{l}\text { Socioeconomic level: } \\
\text { - High } \\
\text { - Moderate } \\
\text { - Low }\end{array}$ & $\begin{array}{l}31 \\
77 \\
42\end{array}$ & $\begin{array}{l}20.7 \\
51.3 \\
28 \\
\end{array}$ \\
\hline $\begin{array}{l}\text { Heath insurance: } \\
\text { - Yes } \\
\text { - No } \\
\end{array}$ & $\begin{array}{l}23 \\
127 \\
\end{array}$ & $\begin{array}{l}15.3 \\
84.7 \\
\end{array}$ \\
\hline $\begin{array}{l}\text { Disease duration: }\left(\bar{X}_{ \pm} \mathrm{SD}\right) \mathrm{p} \\
\text { Range }\end{array}$ & \multicolumn{2}{|c|}{$\begin{array}{l}7.71 \pm 4.8 \\
1-26\end{array}$} \\
\hline
\end{tabular}


Table (2): Relationship between patient adherence to medication and sociodemographic characteristics $(\mathrm{N}=150)$ :

\begin{tabular}{|c|c|c|c|c|c|c|}
\hline \multirow{3}{*}{ Socio demographic characteristics } & \multicolumn{4}{|c|}{ Adherence } & \multirow{3}{*}{$\chi^{2}$} & \multirow{3}{*}{ p value } \\
\hline & \multicolumn{2}{|c|}{$\begin{array}{l}\text { Low } \\
(n=83)\end{array}$} & \multicolumn{2}{|c|}{$\begin{array}{l}\text { Moderate } \\
(n=67)\end{array}$} & & \\
\hline & No. & $\%$ & No. & $\%$ & & \\
\hline $\begin{aligned} & \text { Gender: } \\
& \text { - } \text { Male } \\
& \text { - } \text { Female }\end{aligned}$ & $\begin{array}{l}38 \\
45\end{array}$ & $\begin{array}{l}45.8 \\
54.2\end{array}$ & $\begin{array}{l}8 \\
59\end{array}$ & $\begin{array}{l}11.9 \\
88.1\end{array}$ & 19.9 & $<0.001$ \\
\hline $\begin{array}{cl}\text { Marital state: } \\
\text { - Single } \\
\text { - } \text { Married } \\
\text { - } \text { Widow } \\
\text { - Divorce }\end{array}$ & $\begin{array}{l}1 \\
69 \\
6 \\
7\end{array}$ & $\begin{array}{l}1.2 \\
83.1 \\
7.2 \\
8.4\end{array}$ & $\begin{array}{l}1 \\
50 \\
6 \\
10\end{array}$ & $\begin{array}{l}1.5 \\
74.6 \\
9 \\
14.9\end{array}$ & 1.87 & 0.59 \\
\hline $\begin{array}{l}\text { Educational level: } \\
\text { - Illiterate } \\
\text { - Primary education } \\
\text { - Secondary or diploma } \\
\text { - University and above }\end{array}$ & $\begin{array}{l}1 \\
50 \\
25 \\
7\end{array}$ & $\begin{array}{l}1.2 \\
60.2 \\
30.1 \\
8.4\end{array}$ & $\begin{array}{l}1 \\
48 \\
14 \\
4\end{array}$ & $\begin{array}{l}1.5 \\
71.6 \\
20.9 \\
6\end{array}$ & 2.28 & 0.52 \\
\hline $\begin{aligned} \text { Occupation: } \\
\text { - Not work } \\
\text { - Worker } \\
\text { - Technician } \\
\text { - Government employee }\end{aligned}$ & $\begin{array}{l}41 \\
4 \\
20 \\
18\end{array}$ & $\begin{array}{l}49.4 \\
4.8 \\
24.1 \\
21.7\end{array}$ & $\begin{array}{l}52 \\
3 \\
6 \\
6\end{array}$ & $\begin{array}{l}77.6 \\
4.5 \\
9 \\
9\end{array}$ & 13.4 & $<0.001$ \\
\hline $\begin{array}{c}\text { Socioeconomic level: } \\
\text { - High } \\
\text { - Moderate } \\
\text { - Low }\end{array}$ & $\begin{array}{l}22 \\
21 \\
40\end{array}$ & $\begin{array}{l}26.5 \\
25.3 \\
48.2 \\
\end{array}$ & $\begin{array}{l}9 \\
21 \\
37 \\
\end{array}$ & $\begin{array}{l}13.4 \\
31.3 \\
54.8 \\
\end{array}$ & 3.9 & 0.14 \\
\hline $\begin{array}{l}\text { Heath insurance: } \\
\text { - Yes } \\
\text { - No }\end{array}$ & $\begin{array}{l}18 \\
65\end{array}$ & $\begin{array}{l}21.7 \\
78.3\end{array}$ & $\begin{array}{l}5 \\
62\end{array}$ & $\begin{array}{l}7.5 \\
92.5\end{array}$ & 5.77 & 0.02 \\
\hline $\begin{array}{l}\text { Age / years } \\
\bar{X}_{ \pm S D}\end{array}$ & 44.2 & & 45.2 & & $\mathrm{t}=1.5$ & 0.13 \\
\hline $\begin{array}{l}\text { Disease duration } \\
\bar{X}_{ \pm S D}\end{array}$ & 6.53 & & 8.66 & & $\mathrm{t}=2.7$ & $<0.001$ \\
\hline
\end{tabular}


Table (3): Environmental Quality of care received by the patient $(\mathrm{N}=150)$ :

\begin{tabular}{|c|c|c|}
\hline Obstacles & No & $\%$ \\
\hline $\begin{array}{l}\text { The time you spend with your doctor is not enough: } \\
\text { - Disagree } \\
\text { - Neutral } \\
\text { - Agree }\end{array}$ & $\begin{array}{l}32 \\
1 \\
117\end{array}$ & $\begin{array}{l}21.3 \\
0.7 \\
78\end{array}$ \\
\hline $\begin{array}{l}\text { Difficult to conduct the necessary tests: } \\
\text { - Disagree } \\
\text { - Neutral } \\
\text { - Agree }\end{array}$ & $\begin{array}{l}70 \\
0 \\
80 \\
\end{array}$ & $\begin{array}{l}46.7 \\
0 \\
53.3 \\
\end{array}$ \\
\hline $\begin{array}{l}\text { Difficulty of access to the center: } \\
\text { - Disagree. } \\
\text { - Neutral. } \\
\text { - Agree. }\end{array}$ & $\begin{array}{l}64 \\
0 \\
86\end{array}$ & $\begin{array}{l}42.7 \\
0 \\
57.3\end{array}$ \\
\hline $\begin{array}{l}\text { The center is far from the place of residence: } \\
\text { - Disagree. } \\
\text { - Neutral. } \\
\text { - Agree. }\end{array}$ & $\begin{array}{l}47 \\
3 \\
100 \\
\end{array}$ & $\begin{array}{l}31.3 \\
2 \\
66.7\end{array}$ \\
\hline $\begin{array}{l}\text { High cost of the services: } \\
\text { - Disagree. } \\
\text { - Neutral. } \\
\text { - Agree. } \\
\end{array}$ & $\begin{array}{l}64 \\
0 \\
86 \\
\end{array}$ & $\begin{array}{l}42.7 \\
0 \\
57.3 \\
\end{array}$ \\
\hline $\begin{array}{l}\text { Non-existence of a doctor } \\
\text { - Disagree } \\
\text { - Neutral } \\
\text { - Agree }\end{array}$ & $\begin{array}{l}106 \\
0 \\
44\end{array}$ & $\begin{array}{l}70.7 \\
0 \\
29.3\end{array}$ \\
\hline $\begin{array}{l}\text { Appointments within the center is not appropriate } \\
\text { - Disagree } \\
\text { - Neutral } \\
\text { - Agree. }\end{array}$ & $\begin{array}{l}63 \\
0 \\
87 \\
\end{array}$ & $\begin{array}{l}42 \\
0 \\
58 \\
\end{array}$ \\
\hline $\begin{array}{c}\text { Long wait time } \\
\text { - Disagree } \\
\text { - Neutral } \\
\text { - Agree }\end{array}$ & $\begin{array}{l}59 \\
0 \\
91 \\
\end{array}$ & $\begin{array}{l}39.3 \\
0 \\
60.7\end{array}$ \\
\hline $\begin{array}{l}\text { The physician showed empathy and understanding of the } \\
\text { condition: } \\
\text { - Disagree } \\
\text { - Neutral } \\
\text { - Agree }\end{array}$ & $\begin{array}{l}100 \\
1 \\
49\end{array}$ & $\begin{array}{l}66 \\
0.7 \\
32.7\end{array}$ \\
\hline
\end{tabular}


Table (4): Assessment of process of care recorded in Diabetic patients files in the past year.

\begin{tabular}{|c|c|c|}
\hline Process of care & No & $\%$ \\
\hline $\begin{array}{l}\text { Blood pressure(check BP at each visit) } \\
\text { - Yes } \\
\text { - No }\end{array}$ & $\begin{array}{l}150 \\
0\end{array}$ & $\begin{array}{l}100 \\
0\end{array}$ \\
\hline $\begin{array}{l}\text { Weight:( at each visit) } \\
\text { - Yes } \\
\text { - No }\end{array}$ & $\begin{array}{l}150 \\
0\end{array}$ & $\begin{array}{l}100 \\
0\end{array}$ \\
\hline $\begin{array}{l}\text { Blood glucose:( at each visit) } \\
\text { - Yes } \\
\text { - No }\end{array}$ & $\begin{array}{l}111 \\
39\end{array}$ & $\begin{array}{l}73.8 \\
26.2\end{array}$ \\
\hline $\begin{array}{l}\text { Test for proteinuria(annual) } \\
\text { - Yes } \\
\text { - No }\end{array}$ & $\begin{array}{l}68 \\
82\end{array}$ & $\begin{array}{l}45.3 \\
54.7\end{array}$ \\
\hline $\begin{array}{l}\text { Peripheral sensation (at each visit) } \\
\text { - Yes } \\
\text { - } \mathrm{No}\end{array}$ & $\begin{array}{l}130 \\
20\end{array}$ & $\begin{array}{l}86.7 \\
13.3\end{array}$ \\
\hline $\begin{array}{l}\text { Peripheral pulse:( at each visit) } \\
\text { - Yes } \\
\text { - No }\end{array}$ & $\begin{array}{l}112 \\
38\end{array}$ & $\begin{array}{l}74.7 \\
25.3\end{array}$ \\
\hline $\begin{array}{l}\text { Foot examination:(at each visit) } \\
\text { - Yes } \\
\text { - No }\end{array}$ & $\begin{array}{l}130 \\
20\end{array}$ & $\begin{array}{l}86.7 \\
13.3\end{array}$ \\
\hline $\begin{array}{l}\text { Ophthalmic examination:(annual) } \\
\text { - Yes } \\
\text { - No }\end{array}$ & $\begin{array}{l}99 \\
51\end{array}$ & $\begin{array}{l}66 \\
34\end{array}$ \\
\hline $\begin{array}{l}\text { Urea and electrolytes:(annual) } \\
\text { - Yes } \\
\text { - No }\end{array}$ & $\begin{array}{l}6 \\
144\end{array}$ & $\begin{array}{l}4 \\
96\end{array}$ \\
\hline $\begin{array}{l}\text { Glycosylated hemoglobin(HA1c)* } \\
\text { Yes } \\
\text { No }\end{array}$ & $\begin{array}{l}16 \\
134\end{array}$ & $\begin{array}{l}10.7 \\
89.3\end{array}$ \\
\hline
\end{tabular}

* Test HA1c every 6 months if controlled; Every three months if not controlled or if change in therapy. 


\section{Adherance among the studied group}

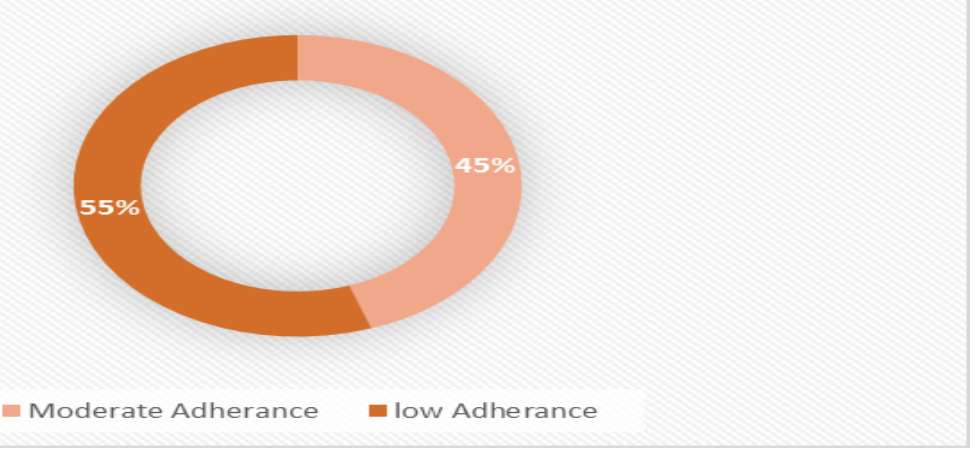

Figure (2) Adherence among the studied groups

\section{OBSTACLES SCORE}

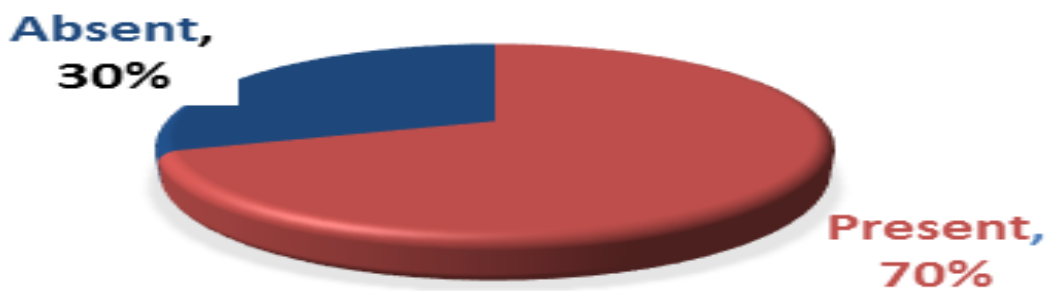

Fig (3): Distribution of study group according to presence of obstacles of care

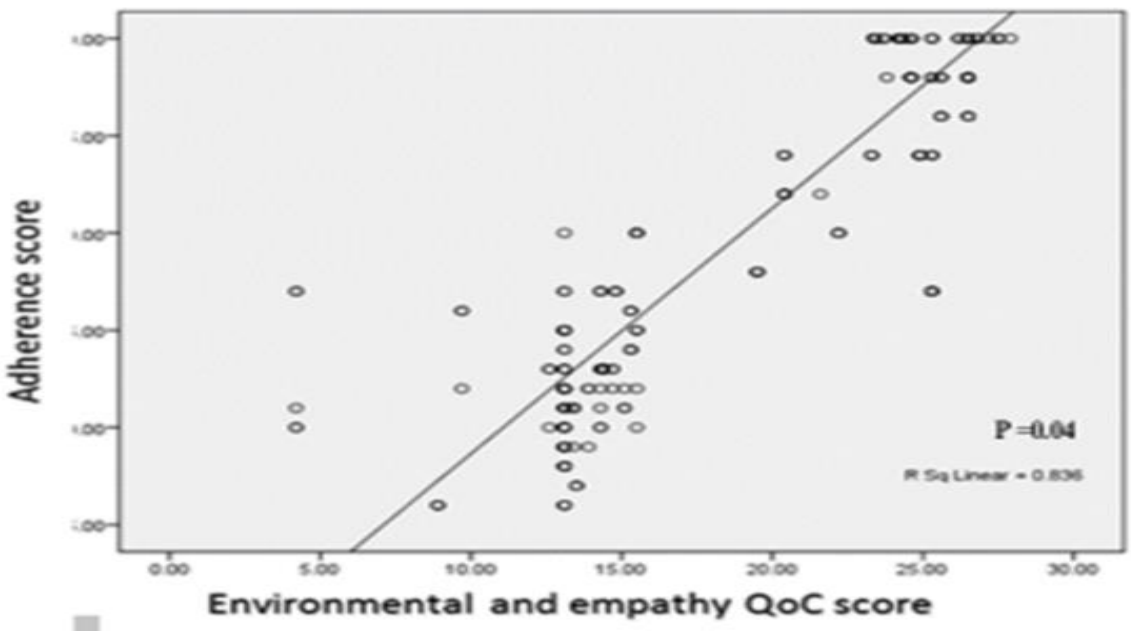

Figure (4): Correlation between medication adherence score and QoC 


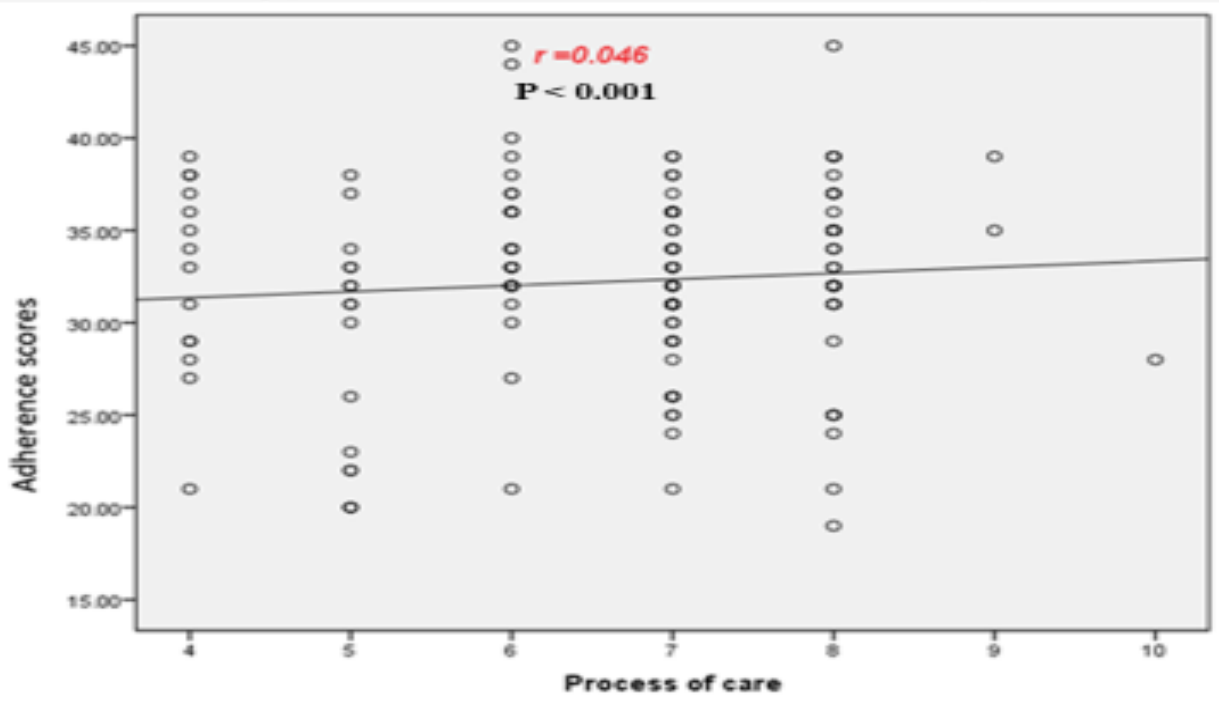

Figure (5): Correlation between medication adherence score and process of care 


\section{جودة الرعاية الصحية والالتزام الدوائي لاي مرضى البوال السكري(النوع الثاني) نجوى نشأت حجازي \\ قسم طب الأسرة- كلية الطب- جامعة المنوفية}

الخلفية: ان مرض السكري هو متلازمة الأيض السائدة في جميع انحاء العالم، مما لا شك فيه أن تحسين الر عاية

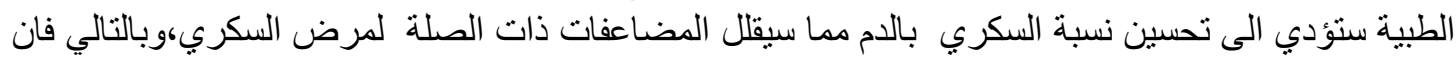

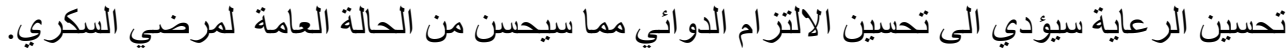

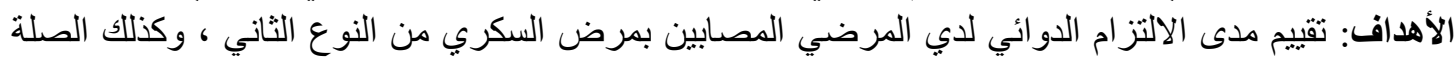

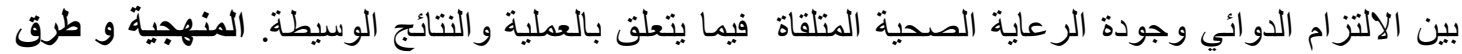
البحث: تم حشد المرضي من النوع الثاني لمرض السكري من عيادة منشأة سلطان للامر اض الخان الخارجية بمركز

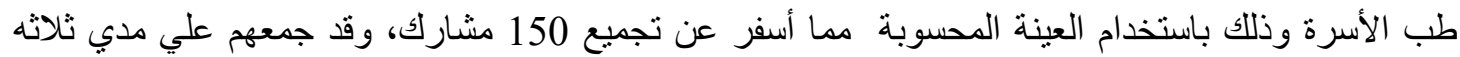

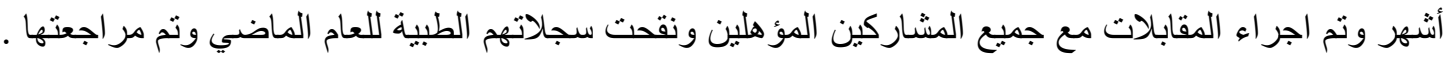

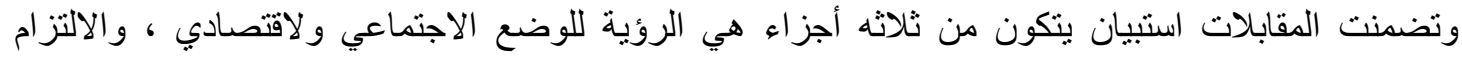

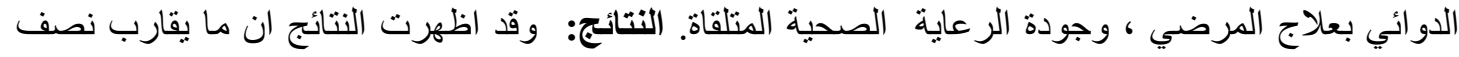

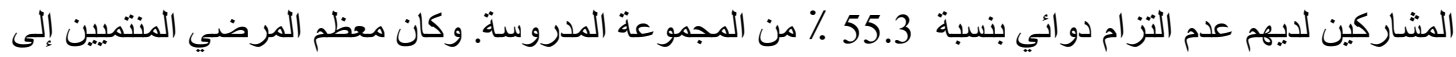

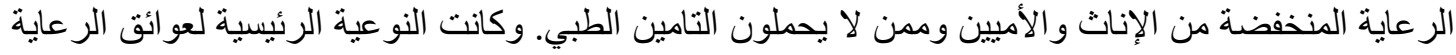

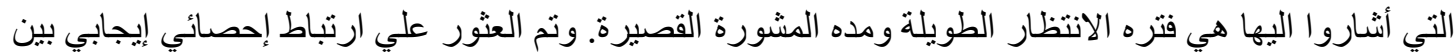

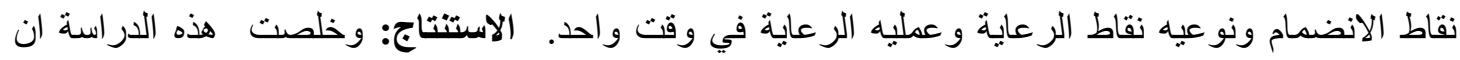

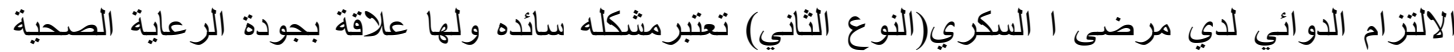

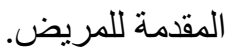

